\title{
ENABLING FACTORS FOR FINANCING AND IMPLEMENTING POSTDISASTER OPERATIONS
}

Junko Mochizuki, Joshua Hallwright, and John Handmer

NO. 594

October 2019
ADB ECONOMICS WORKING PAPER SERIES 


\section{Enabling Factors for Financing and Implementing Postdisaster Operations}

Junko Mochizuki, Joshua Hallwright, and John Handmer

No. 594 | October 2019
Junko Mochizuki (mochizuk@iiasa.ac.at) is a research scholar at the International Institute for Applied Systems Analysis (IIASA), Joshua Hallwright

(joshua.hallwright@rmit.edu.au) is a PhD candidate at the Royal Melbourne Institute of Technology (RMIT)

University, John Handmer (john.handmer@rmit.edu.au) is a professor at the same university and a guest scholar at IIASA.

This paper was prepared as background material for the Asian Development Outlook 2019 theme chapter on

"Strengthening Disaster Resilience." 
(C) 2019 Asian Development Bank 6 ADB Avenue, Mandaluyong City, 1550 Metro Manila, Philippines

Tel +632632 4444; Fax +6326362444

www.adb.org

Some rights reserved. Published in 2019.

ISSN 2313-6537 (print), 2313-6545 (electronic)

Publication Stock No. WPS190479-2

DOI: http://dx.doi.org/10.22617/WPS190479-2

The views expressed in this publication are those of the authors and do not necessarily reflect the views and policies of the Asian Development Bank (ADB) or its Board of Governors or the governments they represent.

ADB does not guarantee the accuracy of the data included in this publication and accepts no responsibility for any consequence of their use. The mention of specific companies or products of manufacturers does not imply that they are endorsed or recommended by ADB in preference to others of a similar nature that are not mentioned.

By making any designation of or reference to a particular territory or geographic area, or by using the term "country" in this document, $A D B$ does not intend to make any judgments as to the legal or other status of any territory or area.

This work is available under the Creative Commons Attribution 3.0 IGO license (CC BY 3.0 IGO)

https://creativecommons.org/licenses/by/3.o/igo/. By using the content of this publication, you agree to be bound by the terms of this license. For attribution, translations, adaptations, and permissions, please read the provisions and terms of use at https://www.adb.org/terms-use\#openaccess.

This CC license does not apply to non-ADB copyright materials in this publication. If the material is attributed to another source, please contact the copyright owner or publisher of that source for permission to reproduce it. $\mathrm{ADB}$ cannot be held liable for any claims that arise as a result of your use of the material.

Please contact pubsmarketing@adb.org if you have questions or comments with respect to content, or if you wish to obtain copyright permission for your intended use that does not fall within these terms, or for permission to use the ADB logo.

Corrigenda to ADB publications may be found at http://www.adb.org/publications/corrigenda.

Note:

In this publication, “\$” refers to United States dollars, unless otherwise stated.

The ADB Economics Working Paper Series presents data, information, and/or findings from ongoing research and studies to encourage exchange of ideas and to elicit comment and feedback about development issues in Asia and the Pacific. Since papers in this series are intended for quick and easy dissemination, the content may or may not be fully edited and may later be modified for final publication.

Printed on recycled paper 


\section{CONTENTS}

ABSTRACT iv

$\begin{array}{ll}\text { I. INTRODUCTION } & 1\end{array}$

II. GOVERNANCE OF POSTDISASTER OPERATIONS AND RISK FINANCE 3

III. CASE STUDIES $\quad 6$

A. 2015 Earthquake in Nepal 6

B. 2015 Cyclone Pam in Vanuatu 10

C. 2010 Flood in Pakistan 13

$\begin{array}{ll}\text { IV. DISCUSSION AND CONCLUSIONS } & 18\end{array}$

$\begin{array}{ll}\text { REFERENCES } & 21\end{array}$

TABLE

Disasters Reviewed in This Report 3

FIGURE

Actor Landscape, Financing Instruments, and Enablers for Postdisaster Operation 


\begin{abstract}
As the economic costs of disasters increase in Asia, recent years have seen wide adoption of policy instruments to support disaster resilience. Many of these instruments-such as sovereign insurance, contingency credit, reserve funds, and forecast-based financing-are designed to provide predictable access to finance in case of catastrophic disasters. Yet providing timely access is only one of the many issues that must be addressed for the complex postdisaster operation to function. Reviewing recent experiences - such as the 2015 earthquake in Nepal, the 2015 Cyclone Pam in Vanuatu, and the 2010 flood in Pakistan-this study first describes the governance complexity commonly seen in the postdisaster contexts, complexities such as the acute inflow of new actors and competing operational objectives. We then identify the potential opportunities, as well as the limitations, of existing financing arrangements in facilitating disaster resilience. In conclusion, we outline five recommendations to building enabling environments.
\end{abstract}

Keywords: disaster resilience, disaster risk finance, governance

JEL code: Q54 


\section{INTRODUCTION}

The past few decades have seen a rapid rise in economic losses caused by disasters in Asia and the Pacific. The region is one of the most disaster-prone areas globally, routinely exposed to hazards such as floods, droughts, typhoons, earthquakes, and tsunamis. The annual losses, averaging approximately $\$ 52$ billion seen in the decade between 2005 and 2014 (during the implementation period of the Hyogo Framework for Action), are expected to increase to as much as $\$ 160$ billion annually by 2030 (UNESCAP 2017). With private insurance coverage as low as $8 \%$ on average in the region (Insurance Asia News 2018), this means that governments, households, and firms bear considerable burdens when a disaster strikes. Against this backdrop, the region has seen considerable efforts to improve economic preparedness including initiatives to transfer and manage risk such as the Pacific Catastrophe Risk Assessment and Financing Initiative (PCRAFI)' and the Southeast Asia Disaster Risk Insurance Facility. ${ }^{2}$

In addition to mobilizing the necessary finances, disaster risk management-including ex ante preparedness and risk reduction and ex post response, recovery, and rebuilding (which we refer to as "postdisaster operations" hereafter) - requires the setting up of appropriate institutions and the mobilization of human resources. One of the important trends seen in the past few years is that those instruments used for the mobilization of financial resources, such as contingency credit mechanisms, are increasingly seen as a means to link risk financing with the operation of disaster risk preparedness and response (Clarke and Dercon 2016). These ex ante financing instruments are used to bridge the financing gap that appears frequently between immediate humanitarian response (financed through humanitarian appeals) and longer-term recovery and reconstruction (financed through development grants and loans). As such, these instruments have the potential to bridge the long-established operational divide between humanitarian and development sectors, but this potential is yet to be fully utilized.

Disaster risk financing has traditionally been framed as an issue of portfolio management with technical assistance provided to (i) estimate the probability and extent of economic and fiscal costs of disasters, (ii) review existing financing mechanisms, (iii) evaluate access to insurance and capital markets, and (iv) quantify potential short-term and longer-term shortfalls in response and recovery operations (IBRD/World Bank and ADB 2017). However, such framing does not adequately address the implementation challenges associated with postdisaster operations.

Past experiences of disaster response, recovery, and reconstruction amply demonstrate that the lack of financial access is certainly not the only barrier to swift postdisaster operations (Hallegatte, Rentschler, and Erik 2018) - and that even with the availability of financing, governments, firms, and households often struggle to recover.

Unpacking the reasons as to why postdisaster operations face major challenges, sometimes despite the availability of finances, allows us to identify those enabling factors that deserve attention. These enabling factors could unleash the potential of ex ante risk financing in bridging the many gaps that exist among different operational stages of the disaster risk management cycle. They also can

\footnotetext{
Pacific Catastrophe Risk Assessment and Financing Initiative (PCRAFI). "Pacific Risk Information System: Open DRI Repository for the Pacific Region providing premiere risk-related geospatial datasets.” http://pcrafi.spc.int/ (accessed 17 May 2019).

2 Southeast Asia Disaster Risk Insurance Facility (SEADRIF). https://www.seadrif.org/ (accessed 28 August 2019).
} 
bridge those gaps that exist between different actors, both domestic and international, and across public, private, and civil society sectors within humanitarian and development operations.

Any governments or other actors interested in setting up an ex ante risk financing arrangement should be aware of common pitfalls that emerge due to governance complexity. Measures should be taken to build an enabling environment before a disaster strikes, so that timely access to financial resources tangibly leads to the timely execution of postdisaster operations.

As will be illustrated in this study, the delivery and use of disaster risk finance are frequently stymied by the complex and multiactor governance landscape of postdisaster operations. Donors and recipient governments may, for example, have differing opinions on who should be in charge of collecting and distributing the acute influx of resources. Or, even when there are preagreements in place, local administrative capacities may be overwhelmed with the due diligence and reporting requirements of highly fragmented donor communities. In other cases, when lacking insights from the private sector regarding the local labor and goods market conditions, governments may underestimate the impact of a postdisaster construction boom, which, combined with limited access to credit, may cause delays in procurement and rebuilding activities (Practical Action 2016). In general, having the clarity of roles and responsibilities of external and internal actors codified in formal frameworks and policy guidelines helps. Nevertheless, without actors' experiential knowledge and sense of trust toward each other, predisaster plans are prone to implementation failures amid the chaos of postdisaster operations. These are common operational pitfalls that can be avoided if there is awareness of them and preparedness investments are made accordingly.

This study also argues that there are many tangible ways in which national governmentsworking together with donors, local government, private sector, and civil society actors-can avoid these common pitfalls and foster enabling environments before a disaster strikes. Those enabling environments may be categorized as constituting both "explicit enablers" (such as setting up appropriate institutions, getting ex ante access to recovery financing, and establishing the clarity of roles and responsibilities by drafting predisaster plans and frameworks) and "tacit enablers" (such as providing opportunities for building trust and experiential knowledge through joint simulation exercises, and fostering operational knowledge and capacities of local staff to handle the complex administrative requirements of multiple currency grants and loans). We argue that both explicit and tacit enablers are equally important preconditions for the successful delivery of risk finance in postdisaster operations.

To provide an overview on this topic, this background paper reviews three major disasters that have occurred in the region (see table on page 3). In section II, we first characterize governing complexities associated with postdisaster operations in general. In section III, we then closely examine the three cases to draw lessons as to what operational considerations are important to better link disaster risk financing to postdisaster operations in Asia and the Pacific. 


\section{Disasters Reviewed in This Report}

\begin{tabular}{|c|c|c|c|}
\hline & 2015 Earthquake in Nepal & $\begin{array}{l}2015 \text { Cyclone Pam } \\
\text { in Vanuatu }\end{array}$ & 2010 Flood in Pakistan \\
\hline Hazard & $\begin{array}{l}\text { Mw } 7.8 \text { earthquake occurred } \\
\text { on } 25 \text { April } 2015 \text { in the region } \\
\text { (approximately } 80 \mathrm{~km} \\
\text { northwest of Kathmandu) }\end{array}$ & $\begin{array}{l}\text { Category } 5 \text { typhoon with } \\
\text { sustained wind speeds of } \\
270 \mathrm{~km} / \mathrm{h} \text { made a landfall } \\
\text { on } 13 \text { March } 2015\end{array}$ & $\begin{array}{l}\text { Unusually heavy monsoon rain } \\
\text { from July to August } 2010 \\
\text { inundated areas around the } \\
\text { northwestern province of } \\
\text { Khyber Pakhtunkhwa }\end{array}$ \\
\hline Deaths and injuries & $\begin{array}{l}8,790+\text { deaths, and affected } 8 \\
\text { million people }\end{array}$ & $\begin{array}{l}11 \text { deaths, affected } 188,000+ \\
\text { people }\end{array}$ & $\begin{array}{l}\text { 1,985+ deaths, affected } 20 \\
\text { million+ people }\end{array}$ \\
\hline Damage and losses & $\begin{array}{l}\text { Over } 750,000 \text { houses } \\
\text { destroyed or damaged; Over } \\
6,000 \text { government buildings } \\
\text { destroyed or damaged; } \\
\text { Damage and losses totaled } \\
\text { approximately a third of GDP }\end{array}$ & $\begin{array}{l}17,000 \text { buildings damaged; } \\
75 \% \text { coconut, } 80 \% \text { coffee, } 80 \% \\
\text { leaf vegetables, and } 70 \% \text { taro } \\
\text { crops destroyed; } \\
\text { Damage and losses totaling } \\
61 \% \text { of GDP }\end{array}$ & $\begin{array}{l}\text { Over } 1.8 \text { million houses } \\
\text { destroyed or damaged; } 515 \\
\text { public health facilities, } 10,407 \\
\text { education facilities, } 25,000 \mathrm{~km} \\
\text { of road and 1,225 km of railway } \\
\text { damaged or destroyed; } \\
\text { Damage and losses totaling } 6 \% \\
\text { of GDP }\end{array}$ \\
\hline $\begin{array}{l}\text { Humanitarian } \\
\text { appeal }\end{array}$ & $\$ 422$ million & $\$ 29.88$ million & $\$ 2,007$ million \\
\hline $\begin{array}{l}\text { Reconstruction } \\
\text { funding }\end{array}$ & $\begin{array}{l}\$ 4 \text { billion pledged at the donor } \\
\text { conference }\end{array}$ & $\begin{array}{l}\$ 147.45 \text { million of } \$ 320.83 \\
\text { million requested }\end{array}$ & $\begin{array}{l}\$ 6.799 \text { billion to } \$ 8.915 \text { billion } \\
\text { from DNA }\end{array}$ \\
\hline \multicolumn{4}{|c|}{$\begin{array}{l}\text { DNA = disaster needs assessment, GDP = gross domestic product, } \mathrm{km}=\text { kilometers, } \mathrm{km} / \mathrm{h}=\text { kilometers per hour, Mw }=\text { moment magnitude of } \\
\text { an earthquake. } \\
\text { Source: Authors' own based on Goda et al. 2015, International Centre for Integrated Mountain Development 2015, Government of Nepal } \\
\text { 2015, National Reconstruction Agency } 2016 \text { (for Nepal); World Food Programme 2015a, World Health Organization 2015, Hallwright and } \\
\text { Handmer 2019, Government of Vanuatu 2015a and 2015b (for Vanuatu); Scott 2011, Government of Pakistan 2010, Asian Development } \\
\text { Bank and World Bank 2010, United Nations 2010a and 2010b (for Pakistan). }\end{array}$} \\
\hline
\end{tabular}

\section{GOVERNANCE OF POSTDISASTER OPERATIONS AND RISK FINANCE}

Governing a postdisaster operation is a complex undertaking. Not least due to the unpredictable availability of external assistance (attributable to factors such as different media coverages, geopolitical considerations, donor fatigue, and disaster and recipient country characteristics (Olsen, Carstensen, and Høyen 2003; Fink and Redaelli 2009; Raschky and Schwindt 2012; Becerra, Cavallo, and Noy 2014), but also due to multiple external and domestic actors that must be mobilized, along with response and recovery priorities that compete for resources under acute time pressure (Olshansky, Hopkins, and Johnson 2012). Following the initial shock of a disaster, lives must be saved; food, clothing, and shelter secured; infrastructure rebuilt; livelihoods reestablished-as quickly, as sustainably, as equitably, and as resiliently as possible.

It is a formidable task for any government working together with other actors to coordinate such efforts while ensuring sufficient finance is available where and when it is needed. This process may be severely hampered when governments and partners themselves are affected by disasters and/or when their predisaster capacities to implement functioning public administration is limited, as seen in many developing countries. As multiple actors rush into rescue and assistance following 
disasters, complex and parallel governance structures emerge (Rahman and Sawada 2012), as shown in the figure below.

\section{Actor Landscape, Financing Instruments, and Enablers for Postdisaster Operation}

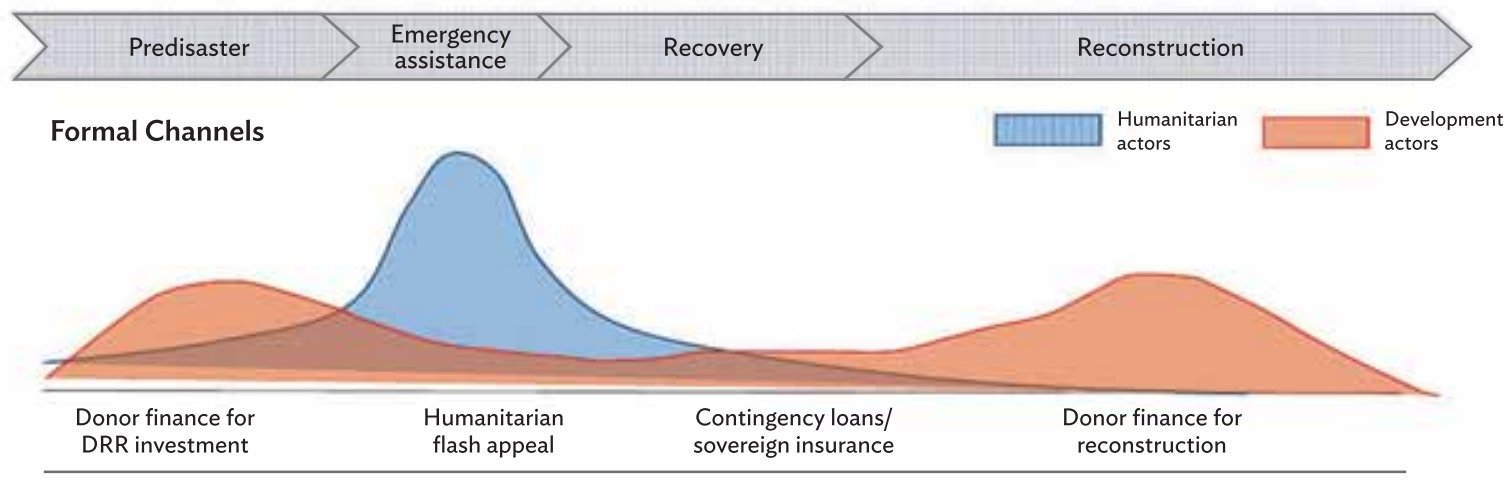

\section{National DRM Mechanisms}

- Disaster risk management institutions (laws, regulations, coordination mechanisms, operational procedures)

- Ex ante disaster finance arrangements (reserve fund, sovereign insurance, contingency finance)

\section{Enabling Factors}

Clarity of expectations Procedural and contextual familiarity Sense of trust and accountability Absorption capacity

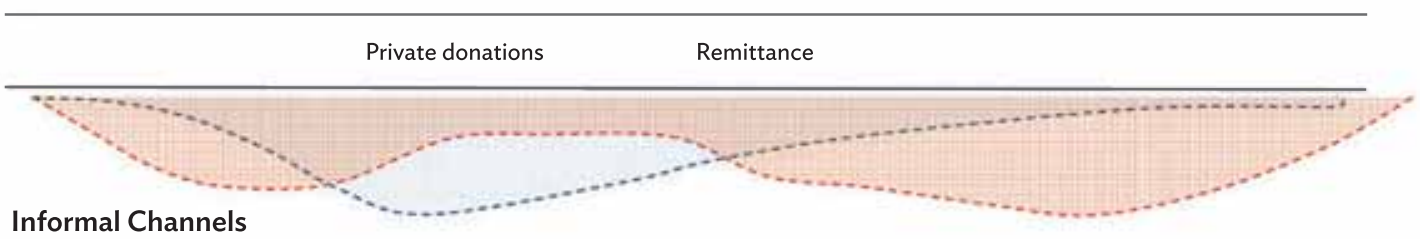

$\mathrm{DRM}=$ disaster risk management, $\mathrm{DRR}=$ disaster risk reduction.

Note: While the amount of incoming funding peaks during the reconstruction phase of capital-intensive infrastructure (Ghesquiere and Mahul 2010), the number of incoming actors tends to surge amid an initial humanitarian response, significantly stretching the coordination needs of governments and partners.

Source: Authors' own

Predisaster and postdisaster operations are financed and implemented by multiple channels and actors. This landscape is often highly fragmented-with a notable divide between formal and informal channels of financing; another between humanitarian and development actors; and a third among public, private, and civil society contributions.

If we look closer at any particular sector, we also find a wide variety of channels through which different actors participating in postdisaster operations raise funds. Take the humanitarian sector, for example. Following the initial onset of a disaster, the International Federation of Red Cross Disaster Relief Emergency Fund may be disbursed within 24 hours for national societies of the Red Cross Red Crescent Movement. The United Nations Development Programme TRAC 1.1.3 disburses funds for the United Nations Development Programme within 2 weeks. There is a similar timeframe for the Central Emergency Response Fund for the United Nations (UN) agencies and for the Office of the Coordination of Humanitarian Affairs Emergency Cash Grants for the UN Humanitarian Coordinators 
or Resident Coordinators (with the possibility of transferring to national authorities and local nongovernment organizations [NGOs]). The Asia Pacific Disaster Response Fund is another funding mechanism managed by the Asian Development Bank (ADB) that can disburse funding for ADB member countries within 4-5 days or as soon as eligibility criteria are met (UNOCHA 2018a). This follows ADB's integrated approach to disaster risk finance. Upon a rapid appraisal of disaster impact, the UN flash appeal is launched collectively. It outlines strategic funding requirements for different humanitarian cluster activities foreseen for the first 3-6 months after a disaster impact. For large-scale disasters, an additional process - known as the consolidated appeal process-may be mobilized.

At the national level, governments may in parallel disburse immediate funds through the use of contingency budgets, budget reallocations, or through domestic and external credit markets (OECD 2015), which may cover medium-term (3-9 months) funding requirements (World Bank/Global Facility for Disaster Risk Reduction 2012). Organizations such as the International Monetary Fund (IMF) extend special funds to low-income countries to address immediate balance of payment concerns (IMF 2018). While immediate humanitarian needs are financed through these funding sources-along with other informal and private contributions-formal channels of funds for long-term recovery and reconstruction are raised based on the postdisaster needs assessment processes and donor conferences that follow (when external assistance and support is requested by the national government). Longer-term reconstruction funds are generally disbursed from around 9 months onward. To bridge funding gaps that may appear between humanitarian assistance and long-term reconstruction, a number of multilateral and bilateral organizations have supported a range of mechanisms. These include regional risk pools, the establishment of national insurance systems, and other ex ante financing options such as World Bank's Catastrophe Deferred Drawdown Option and Japan International Cooperation Agency's Stand-by Emergency Credit for Urgent Recovery (IBRD/World Bank and ADB 2017; Hallegatte, Rentschler, and Erik 2018). ${ }^{3}$

Unlike immediate humanitarian relief operations, which are coordinated at the national level and supported at the international level through an established protocol of cluster approach, longterm recovery and reconstruction are primarily led by national, subnational, and local governments. These typically operate in a less coordinated fashion (Lloyd-Jones 2006), as the national, subnational, and local institutions may have limited capacities to design and implement complex infrastructure and livelihood rebuilding projects.

Another important, and often overlooked, feature of the postdisaster operational environment is the dual system of formal and informal actors and channels of resources. Community members providing mutual support and the voluntary contributions of private individuals and organizations, including the flow of remittances, form an important source of financing for the affected communities to recover. Development Initiatives (2018), for example, estimates that the international humanitarian system globally has received $\$ 27.3$ billion of funding in 2017 , of which $\$ 6.5$ billion was from private sector contributions. Individual giving is the largest source of private contribution (approximately twothirds) and the remaining are contributions from private firms, foundations, and organizations (Development Initiatives 2018).

3 A comprehensive review of ex ante financing instruments is beyond the scope of this present research. Readers interested in this topic can find further information through, for example, Mechler (2004); Hochrainer-Stigler (2006); Ghesquiere and Mahul (2010); OECD (2015); IBRD/World Bank and ADB (2017); World Bank (2017a); and Hallegatte, Rentschler, and Erik (2018). 
As can be easily imagined, navigating and coordinating these diverse channels of funds and operations pose considerable challenges to affected governments and partners. Throughout these postdisaster operations-as will be illustrated in the following case studies - the number of participating actors in this governance system continuously rises and falls, as newcomers bringing new sets of resources, expertise, and expectations that may complement or conflict with the predisaster institutional set up and actor dynamics. An important job of national governments-working together with donors, local government, private sector, and civil society actors-is therefore to anticipate these complexities, understand alternative options for facilitating smooth system functioning, and prepare during predisaster times.

The assessment and design of risk financing options have conventionally been implemented as a technical exercise comparing probabilistic hazard occurrence, economic damage, and a country's access to domestic and external resources. Yet, more can be achieved in facilitating the financing and implementation of postdisaster operations if actors look closer at different needs and capacities that exist within a country (how well they could work with external assistance), to make sound use of such resources. If national governments and partners are aware, for example, that community members themselves-not emergency services - are often the first to respond in case of disasters, then they may decide to allocate more resources for community-based preparedness activities. If they are concerned that line ministries, disaster risk management authorities, and development actors are unfamiliar with the procedural requirements of the cluster approach and humanitarian flash appeals (and likewise donor communities unfamiliar with national disaster risk management legal and procedural requirements), they may allocate resources for predisaster mutual exchange and capacity building activities.

Such insights may come both from learning based on past disasters in similar contexts and from understanding country-specific predisaster socioeconomic contexts such as local networks, knowledge, and capacities - which should form an integral component of discussions when making predisaster arrangements for financing postdisaster operation. Contingency and recovery planning backed by prefinancing can be a useful vehicle to bring appropriate actors to the table and clarify different expectations before a disaster hits. The following section overviews three major disasters that occurred in the Asia and Pacific region over the past decade to draw out important operational considerations to financing and implementing postdisaster operations. Lessons from these cases are distilled at the end as five recommendations for fostering enabling environments in Asia and the Pacific.

\section{CASE STUDIES}

\section{A. 2015 Earthquake in Nepal}

Nepal, located in the southern skirt of the Himalayan mountains, is faced with a number of hazards, such as floods (including glacial lake outburst floods), landslides, earthquakes, windstorms, and hailstorms. As much as $80 \%$ of the country's population is exposed to these hazards (Government of Nepal 2017). The 2015 earthquake-with an initial shock of 7.8 magnitude quake and some 300 aftershocks above 4.0 magnitude that followed-was the largest disaster that Nepal has faced since the 1934 Nepal-Bihar earthquake that killed over 15,000 people in India and Nepal combined. 
The earthquake resulted in over 8,790 deaths; 22,300 injuries; displaced 2.8 million people (International Centre for Integrated Mountain Development 2015); and affected 8 million people, or approximately a third of Nepal's population (Government of Nepal 2015).

Devastation was widespread well beyond the epicenter, located approximately 80 kilometers northwest of Kathmandu. Of Nepal's 75 districts, 14 were classified as "crisis hit" and received targeted support for rescue and relief operations (IMF 2015). On April 29th, a UN flash appeal was launched by 78 participating organizations, requesting $\$ 422$ million, initially over the following 3 months, then later extended to 5 months to accommodate additional needs during the monsoon season (UNOCHA 2015a).

Accordingly, the Post-Disaster Needs Assessment, released 2 months following the initial earthquake, estimated that total costs of damages and losses were approximately $\$ 7$ billion or equivalent to a third of the country's gross domestic product (GDP). The housing and human settlement sector accounted for approximately $50 \%$ of the total estimated damage and losses (Government of Nepal 2015). The country's GDP was projected to decline by approximately $1.6 \%$ during 2014-2015 due to factors such as declines in agricultural outputs and tourism income (IMF 2015). In the months following the onset of disaster, the value of remittances increased by $20 \%-35 \%$, according to the estimates by major remittance companies (UNOCHA 2015b).

The IMF projected that a decline in tourism income and an increase in import needs for recovery and reconstruction were expected to offset a higher inflow of remittance pushing the country's current account into a deficit of approximately 4\% of GDP over the following 5 years. The IMF subsequently approved a disbursement of a special drawing rights of SDR35.65 million (\$49.7 million) in direct budgetary support to the Ministry of Finance under the Fund's rapid credit facility (IMF 2015). ${ }^{4}$

On 25 June 2015, the Government of Nepal hosted an international conference on Nepal's reconstruction. At this event, donor communities pledged $\$ 4.4$ billion in grants and loans to support the country's recovery and reconstruction-more than twice the amount expressed by the government's initial call for donor support (IMF 2015). To facilitate the reconstruction of the housing sector in the hardest hit 14 rural districts, the Nepal Earthquake Housing Reconstruction Program Multi-Donor Trust Fund was established with support from the United States Agency for International Development, the Swiss Agency for Development and Cooperation, and the World Bank. In May 2016, the government published a 5-year Post Disaster Recovery Framework outlining five strategic foci: (i) restore and improve disaster resilience buildings, (ii) community disaster reduction and social cohesion, (iii) restore and improve access to services, (iv) develop and restore livelihoods, and (iv) build state's capacity to respond to future disasters (National Reconstruction Agency 2016).

The immediate response activities following the earthquake were seen by many as largely successful thanks to the years of investment in disaster risk reduction efforts in the country (Logistics Cluster 2015). The Government of Nepal, working with donors and NGOs, has invested considerable time and resources prior to the 2015 earthquake, including an effort to revise an outdated legal basis for disaster management (which unfortunately remained unfinished at the time of the disaster). But, a number of other efforts-including clarifying formal roles and responsibilities of domestic and international actors, setting up standard operating procedures for crisis response activation, and

$4 \$ 1=$ SDR0.72 as of 14 May 2019. 
ensuring contextual familiarity of actors with long-term presences in Nepal-helped facilitate swift response activities.

The National Disaster Response Framework (NDRF) created in 2013, for example, streamlined the international humanitarian cluster coordination structure with national line ministries, designating each national ministry as cluster lead and international humanitarian agency as colead of 11 clusters. The NDRF further itemized a detailed timeline and responsibilities of 62 action items to be taken up immediately 1 month following an initial hazard event. Some examples of these action items are: (i) an activation of UN clusters within 24 hours, (ii) visa fees and custom duty exemptions for land and air entries of humanitarian assistance within 48 hours, (iii) rapid assessment of existing infrastructure within 72 hours, and (iv) cash and other assistance to victims starting from the second week onward (Government of Nepal 2013).

Following these operational procedures, the Ministry of Home Affairs National Emergency Operation Center convened the first meeting of the Central Natural Disaster Relief Committee within 2 hours of the initial shock. Within 4 hours, the Prime Minister's Disaster Relief Fund was also activated. The clustering mechanism of 11 sectors were also activated within days that immediately followed. Postdisaster surveys revealed that 30 out of 62 mandatory emergency operation activities were performed in line with the framework (Bisri and Beniya 2016). In parallel to the NDRF, the Nepalese Inter-Agency Standing Committee was also established in 2013, with each cluster meeting monthly to discuss key disaster preparedness issues. Based on these efforts, the logistics cluster, for example, began constructing a humanitarian staging area, next to the Tribhuvan International Airport in Kathmandu, in 2013. The staging area was inaugurated in March 2015-just 1 month prior to the earthquake (World Food Programme 2015b). Many believe that these predisaster activities have greatly facilitated immediate activation of rescue and relief activities (Logistics Cluster 2015; Cook, Shrestha, and Bo 2016).

While these predisaster activities have certainly helped coordinate immediate response activities in Nepal, a number of concerns were also raised. These include, for example, a rapid surge of new actors within the cluster system. In the shelter cluster alone, the onset of the disaster saw a significant increase in the number of actors-from approximately 10 agencies that regularly participated in the cluster previous to the earthquake to 120 agencies that needed additional coordination (Inter-Agency Standing Committee 2016). Also raised were concerns regarding the limited inclusion of national NGOs and local actors in the official coordination discussions. Out of $\$ 422$ million in the consolidated humanitarian appeal made by 78 organizations, only $0.8 \%$ of the funds were directed to Nepali organizations (Bisri and Beniya 2016). The formal cluster system also did not address the coordinating needs of national NGOs and local actors, requiring smaller organizations to work outside of it (Inter-Agency Standing Committee 2016; Bisri and Beniya 2016; Cook, Shrestha, and Bo 2016).

The difficulty of collaboration between international, national, and local actors was identified as one of the key challenges. Unbalanced allocation of goods and services were also seen in many areas (Cook, Shrestha, and Bo 2016). These local implementation challenges occurred in spite of UN's first ever mobilization of Nepali staff working outside Nepal to join in response activities (Cook, Shrestha, and Bo 2016).

Relief efforts were hampered by other factors pertaining to logistical difficulties (Hall et al. 2017; Dahal 2016; Grünewald and Burlat 2016; Cook, Shrestha, and Bo 2016). In many instances, due 
to complex topography and these implementation challenges, community members had to help themselves (Auerbach 2015).

Despite generous pledges made by donor communities, Nepal's reconstruction has also faced numerous implementation challenges. As of April 2018, 3 years following the earthquake, only 16\% of the total reconstruction pledges have been disbursed and 25\% of agreements for loans and grants to be made by nine countries remain unsigned so far (Giri and Mandal 2018). Against the official goal of rebuilding 400,000 homes by the end of the 2018 fiscal year, about a quarter have been completed (Giri and Mandal 2018).

There are a number of reasons why Nepal's reconstruction has been slow. The National Reconstruction Agency (NRA) - a special agency set up to oversee rehabilitation and reconstruction projects over 5 years-for example, was stymied from its inception (AsiaNews 2015, Sharma et al. 2018). The NRA was originally proposed through an ordinance prior to the June donor conference, which became void in September of 2015. It was not until January 2016 that the NRA held its first board meeting and began its activities.

The NRA also faced a number of challenges in accessing finance and implementing reconstruction projects. Grants and loans pledged by the donors come in many forms that require separate negotiations (Giri and Mandal 2018). In addition, the National Reconstruction Fund-a centrally managed account for reconstruction and rehabilitation-has not functioned as hoped due to the lack of procedural guidelines (Onlinekhabar 2018). Meanwhile, the Nepalese diaspora community, through embassies and student organizations at universities around the globe, offered generous support to the Prime Minister's Disaster Relief Fund estimated at NPR1.6 billion (or approximately $\$ 14.2$ million) (South Asian Watch on Trade, Economics, and Environment 2018a). ${ }^{5}$

Even when finances are secured at the national level, reconstruction projects face implementation challenges at the local level due to difficulties in matching the supply and demand of materials and skillsets (SAWTEE 2018a, 2018b; Grünewald and Burlat 2016). The local institutional setup and financial infrastructure also hindered swift implementation (Grünewald and Burlat 2016; South Asian Watch on Trade, Economics, and Environment 2018b.) A longitudinal survey conducted in the 11 affected districts shows that communities with better road access, higher initial wealth, and traditional labor sharing practices (known as parma) recovered faster; while other areas lagged behind (Asia Foundation 2017). As of April 2017, more than 60\% of people in severely affected districts still lived in temporary shelters. Of these, $93 \%$ reported that they hadn't yet rebuilt houses because they lacked financing, while $43 \%$ reported that they hadn't yet rebuilt houses because they were on a waiting list to receive cash grants from the Rural Housing Reconstructing Program (Asia Foundation 2017).

These challenges occurred in spite of the progress made in streamlining reconstruction processes (e.g, the publication of guidelines for developing settlements, distributing subsidies, and training and deploying personnel, and of a design catalog for earthquake-resistant building prototypes.) The NRA has since revised its organizational structure to allow for further decentralization of authority (SAWTEE 2018b).

$5 \$ 1=$ NPR113.16 as of 14 May 2019. 
Nepal's case study illustrates common governance challenges of financing and implementing postdisaster operation. Nepal has made mixed progress on reconstruction and recovery as of the time of writing. According to the official statistics published on 2 May 2018, out of 379 public buildings to be rebuilt, 220 have been rebuilt with 147 additional houses under construction; out of 7,553 educational facilities to be rebuilt, 3,613 have been completed with 1,719 under construction; out of 753 cultural heritage structures to be rebuilt, 100 have been completed and 329 are under construction; of 1,197 health institutions to be rebuilt, 586 have been completed and 180 are under construction; of 3,212 drinking water systems to be rebuilt, 581 have been completed and 795 are under construction (National Reconstruction Agency 2018). Full livelihood recovery remains challenging especially for those living in remote areas with initially low incomes and those still residing in temporary shelters (Asia Foundation 2017).

\section{B. $\quad 2015$ Cyclone Pam in Vanuatu}

Vanuatu is the country most at risk of disasters worldwide (Garschagen et al. 2016). Even though the ongoing volcanic eruption in the north of the country is the most recent example, the predominant hazards are tropical storms and cyclones. Tropical Cyclone Pam was the most intense tropical cyclone in the southern hemisphere in 2015 and the second most intense tropical cyclone on record in the South Pacific Ocean. It made landfall on the evening of 13 March 2015. The Category 5 cyclone had wind speeds at 1 minute of 270 kilometers per hour $(\mathrm{km} / \mathrm{h})$, at 10 minutes of $250 \mathrm{~km} / \mathrm{h}$, and a reported maximum gust of $320 \mathrm{~km} / \mathrm{h}$ (Handmer and Iveson 2017). The previous most damaging cyclone to hit Vanuatu was the Category 3 Cyclone Uma in 1987.

Damage was extensive, especially on the islands of Efate, around Port Vila and on the southern islands of Tanna and Eromango. During the storm, 11 people were killed, but it is likely that the high levels of community preparedness, timely and accurate hazard warnings, and community responsiveness significantly reduced the potential impact (Handmer and Iveson 2017). As the cyclone approached, the Vanuatu Meteorology and Geo-Hazards Department sent warnings via short message service (or text messaging), direct phone calls, high frequency radio, and the internet. Despite the destruction of mobile phone towers and high-frequency antennas, warnings were still received by many via the internet (Government of Germany 2016). Damage was most prevalent on the larger islands of Efate, Erromango, and Tanna. Approximately 65,000 people were displaced from their homes. Estimates were of 17,000 buildings damaged or destroyed, including houses, schools, public health clinics, and other medical facilities. The tropical cyclone destroyed the vast majority of crops and compromised the livelihoods of at least $80 \%$ of Vanuatu's rural population.

Estimated damage and losses to the Ni-Vanuatu economy exceed 60\% of GDP (IMF 2016). GDP was projected to decline by $2 \%$ in 2015 . However, GDP actually only declined by $0.8 \%$, due to large influxes of external grants and loans, as well as the accompanying activities from the postdisaster operations. A wide trade deficit in goods and services-driven by cyclone damage to export facilities and a boost to imports from domestic shortages and postdisaster operations-put significant pressure on international reserves. For 2015, IMF projections were for a current account deficit of $27 \%$ of GDP and a budget deficit of 12\% of GDP from reconstruction spending (IMF 2016).

The Government of Vanuatu, in partnership with UN Disaster Assessment and Coordination, conducted rapid assessments to inform the flash appeal, launched on 24 March 2015. This initially called for $\$ 29.88$ million in response funding from international donors (UNOCHA 2015c). The Humanitarian Action Plan (HAP), published 1 May 2015, reiterated the request and left the appeal 
amount unchanged (Government of Vanuatu 2015a). The international community contributed more than the appeals requested, a rarity in disaster response financing, with $\$ 37.04$ million going to the country during the response. Importantly, only $\$ 21.9$ million of the $\$ 37.04$ million contributed to the response went through the formal HAP channels. The relatively high levels of funding are partly due to the small nominal figures being requested. That is, compared to other 2015 disasters, such as the Nepal earthquake which had a HAP at $\$ 422$ million, the Tropical Cyclone Pam appeal was very small (Hallwright and Handmer 2019).

$\mathrm{Ni}-\mathrm{Vanuatu}$ communities have been preparing for and responding to cyclones and other natural hazards for generations. The surprisingly low death toll (just 11 died from a population of 276,000), and the ability of the Ni-Vanuatu people to rebuild their homes and reestablish important livelihood activities in a short timeframe (85\% of households replanted their subsistence gardens within weeks) exemplified this community resilience (Barber 2015). Additionally, communities that had previously been supported by international organizations to establish village-level disaster preparedness committees and otherwise to prepare for disasters more explicitly were able to substantially mitigate the impact of the cyclone, as well as be highly responsive to the disaster (Barber 2015). This emphasis on support from external agencies with a long history in Vanuatu continues today, with evidence emerging that communities who worked with CARE Australia to set up and test their community committees in and around the Ambae volcano are those that were most effectively able to respond.

In addition to existing community resilience, external support has been a key factor in responding to disasters in Vanuatu. Oxfam, in consultation with others, established the Vanuatu Humanitarian Team (VHT) in 2011 as a network of NGOs with strong disaster management capacity, to address "repeated shortcomings and inefficiencies" of the disaster management system in Vanuatu (Barber 2015). The VHT built and maintained trust across the participating NGOs and with government line ministries, tacitly enabling stronger postdisaster operations. In the days following Tropical Cyclone Pam in March 2015, this trust proved instrumental in the initial coordination efforts. However, as rapid external surge support arrived, new trusting relationships had to be established quickly. The success of these efforts was challenged by a perception from the existing VHT organizations that, in general, the staff comprising the external surge support were not sufficiently respectful of the existing experiential knowledge of the VHT organizations and local governments (Barber 2015).

The Government of Vanuatu had not experienced a disaster at the scale of Tropical Cyclone Pam previously, nor had it experience in absorbing the vast increase in multiple currency grants and loans. The large increase in donors (10 in 2008, 16 in 2014, 35 immediately after Tropical Cyclone Pam in 2015) made it difficult for the government to coordinate the response (Government of New Zealand 2017; Vachette, King, and Cottrell 2017). This led to a fragmented donor landscape (including fragmented donor requirements for financing proposals), further complicating operational coordination and the implementation of multiple grants and loans (Government of Germany 2016, Government of New Zealand 2017).

More specifically, this highlights the lack of localization of the response, as donors contributed predominantly to international organizations rather than local responders. Response funding went overwhelmingly to the international humanitarian sector, international NGOs, and UN agencies, with only a small dollar amount ( $\$ 2.785$ million) and small percentage of overall funds (6.4\%) going directly to the Government of Vanuatu (Hallwright and Handmer 2019). 
In contrast to most regions, many countries in the Pacific activate their disaster management structures between disasters (Barber 2015). This allows for greater localization of responses and harmonization of anticipatory activities, possibly accounting for the low death toll following Tropical Cyclone Pam (Handmer and Iveson 2017). However, low levels of resourcing and budget allocations to the National Disaster Management Office (NDMO) (e.g., VUV24.4 million [\$210,454] for the NDMO from a 2014 budget of VUV14.213.8 billion [\$122.59 million]; NDMO received just $0.17 \%$ of the national budget allocation) had reduced the ability to test readiness through measures such as simulation exercises (Government of Vanuatu 2014, Government of Australia 2017). ${ }^{6}$

Low ex ante resourcing and prioritizing of disaster management, coupled with the low levels of experiential knowledge of key disaster management staff, resulted in a lack of familiarity with government procedures, especially those concerned with engaging the international community. The existing procedures to appeal for international assistance-a request generated by NDMO and passed to the Ministry of Foreign Affairs then to High Commissions-were not followed (Barber 2015). Government ex ante financing mechanisms did not provide a large source of financing for postdisaster operations in Tropical Cyclone Pam, only totaling $\$ 6.16$ million. The payout from a small sovereign risk insurance cover was just the second payout from the new PCRAFI (the first being to Tonga in 2014) and the national government received just $\$ 1.9$ million within 10 days of the cyclone. The Emergency Relief Fund spent VUV242.3 million ( $\$ 2.27$ million) from its VUV248 million ( $\$ 2.323$ million) capacity. Finally, the Public Finance and Economic Management Act allows for supplementary allocation of up to $1.5 \%$ of total budget appropriation for that fiscal year. At the time of Tropical Cyclone Pam, this amounted to just $\$ 1.99$ million (Government of Germany 2016).

Interestingly, despite the global growth in cash transfer programming in postdisaster operations, it had not been done in the Pacific before Tropical Cyclone Pam (Hobbs and Jackson 2016). This type of assistance provides cash (or a form of cash) directly to residents impacted by the disaster event, restoring their agency in contexts in which they are usually treated as "beneficiaries." The cash transfer program (CTP) in Tropical Cyclone Pam was very small but has triggered a trend toward CTP in the Pacific, with one small project in Tropical Cyclone Winston in Fiji and a much larger effort in response to the ongoing volcanic eruptions on Ambae island (Oxfam 2019). Unlike many countries, Vanuatu does not have a government social welfare system and so any CTP efforts have been unable to support ongoing social welfare (Hobbs and Jackson 2016).

The National Recovery and Economic Strengthening Program Plan was developed then launched on 16 June 2015, 6 weeks before the HAP expired on 30 July 2015. The plan calls for $\$ 320.827$ million for the recovery over 4 years, ending 31 May 2019 (Government of Vanuatu 2015b). This financing aimed to fund activities in six major sectors: productive, social, infrastructure, environment, social and household, and disaster risk management. The majority of funding in the recovery phase has been in the infrastructure sector. As an example, the total committed for transport rehabilitation and recovery from donors was $\$ 53.9$ million, whereas the government only requested $\$ 36.9$ million in the plan (Government of Vanuatu 2015b).

The donor community has contributed $\$ 147.45$ million to the recovery efforts following Tropical Cyclone Pam. On 5 June 2015, the Executive Board of the IMF approved a disbursement of the equivalent of SDR8.5 million (about $\$ 11.9$ million or $50 \%$ of the quota) under the rapid credit facility (a loan) and a purchase to the equivalent of SDR8.5 million under the rapid financing

$6 \quad \$ 1=$ VUV115.94 as of 14 May 2019. 
instrument (a grant) (IMF 2016). These were both intended to assist the government's balance of payment needs and to catalyze further donor support for recovery from Tropical Cyclone Pam. The World Bank and the largest bilateral donor-Australia's Department of Foreign Affairs and Tradehave provided $\$ 50$ million and $\$ 26.642$ million, respectively. This recovery financing has been predominantly for large infrastructure projects, many of which have been substantially delayed, due to absorptive capacity constraints and delays in contracting international suppliers (ADB 2017).

The large resources contributed to the recovery effort are a testament to both the Government of Vanuatu and the international donor community recognizing the importance of postdisaster operations and financing them appropriately. Importantly, there seems to be more trust in contributing to government budgets and ministries in the recovery phase than in the response phase. In the former, the Government of Vanuatu is the explicit recipient of almost all the $\$ 147.45$ million contributed; and in the latter, of only $\$ 2.785$ million (Hallwright and Handmer 2019).

Despite a fragmented, complex international response to Tropical Cyclone Pam, large humanitarian assistance was provided: \$37.04 million, excluding foreign military assets provided during the response phase. Ex post financing was predominantly comprised of external grants, mainly to international organizations, some of which did not have an in-country presence prior to Tropical Cyclone Pam. Those organizations with an ongoing presence in Vanuatu were best able to respond in a timely, culturally appropriate, and effective manner. It was these organizations that had existing relationships with various government line ministries. Ex ante financing was limited to government budgetary contingencies and the sovereign insurance coverage of the PCRAFI. The scale of the damage and loss from Tropical Cyclone Pam, and the complexity of the multiple currency grants and loans entering the country for postdisaster operations, put a great deal of pressure on government staff, few of whom had the experience or familiarity with these external processes to take full advantage of the international assistance while retaining $\mathrm{Ni}$-Vanuatu sovereignty and dignity. Recovery and reconstruction projects continue, with many $\mathrm{Ni}$-Vanuatu communities still feeling the impact of Tropical Cyclone Pam almost 4 years afterward.

\section{2010 Flood in Pakistan}

The flooding of Pakistan's Indus River that began in July 2010 created one of the greatest humanitarian emergencies in recent history, affecting more than 20 million people, killing over 1,985 and destroying or damaging at least 1.8 million homes. At the time of the disaster, Pakistan had a population of approximately 168 million people, $22.6 \%$ of whom lived below the international poverty line. The floods and resulting damage and losses affected one in every eight Pakistanis (ADB and World Bank 2010). Accordingly, the response to the floods was massive, with the Government of Pakistan, UN agencies, foreign governments, and international and local NGOs providing nearly $\$ 3$ billion worth of aid in the first 12 months (Kirsch et al. 2013). ADB and World Bank (2010) estimate that the overall postdisaster operational costs are between $\$ 8.7$ and $\$ 10.9$ billion.

The physical area and number of people affected by the 2010 floods exceeded the combined total of the 2004 Indian Ocean tsunami that impacted 14 countries, the 2005 earthquake, and the 
2010 Haiti earthquake (Murtaza et al. 2011). ${ }^{7}$ The floods directly and indirectly affected 84 of Pakistan's 121 districts and at one point, over one-fifth of the country (an area larger than England) was underwater (United Nations 2010a, 2010b).

The floods began in late July, following heavy monsoon rains that lasted for more than 8 weeks. In 1 week, Khyber Pakhtunkhwa (KPK) received 9,000 millimeters of rainfall-10 times as much as the province normally receives in the course of an entire year (United Nations 2010a). The disaster evolved from normal flash floods into a catastrophe affecting significant parts of the country, with river flows in the Swat and Kabul rivers being 160\% greater than the historic 1929 floods (Hashmi et al. 2012). Floodwaters washed from north to south down the Indus River, which expanded to roughly 40 times its usual size. The provinces of Balochistan and KPK were flooded first, however, by the middle of August, waters had flowed south and flooded widespread areas of Punjab and Sindh provinces (Polastro et al. 2011). Sindh was the worst affected of the provinces, as the Indus could not dissipate due to the flat topography of the province. While waters receded within days in Balochistan and KPK, it took several weeks in Punjab and months in some areas of Sindh. Even in January 2011, entire union councils were still underwater in four districts of Sindh and one district in Punjab (Polastro et al. 2011).

The Pakistani government quickly asked for international assistance as the scale of the disaster overwhelmed the government's resources. A structure for dedicated federal and provincial funds for disaster risk management has been established under the National Disaster Management Act 2010. However, challenges remain in operationalizing the funds and standardizing procedures across provinces. Furthermore, in the case of the federal government, supplementary grants are typically used for the provisioning of postdisaster funds and the required contingent funds are initially met by reappropriation from the surplus heads, such as unused salary budget (World Bank 2015). The National Disaster Management Authority (NDMA) had only $\$ 0.74$ million operational budget and consisted of only 21 staff at the time of the 2010 floods (NDMA 2011).

Provincial and district authorities responsible for disaster management were equally poorly resourced and had staff with low experiential knowledge of disaster management, with the exception of KPK (NDMA 2011). The broader government resources had been depleted due to the ongoing insurgencies and budget priorities for the War on Terror, the existing humanitarian needs of 1.7 million Afghan refugees, the recovery from the 2005 earthquake and one of the world's lowest tax-to-GDP ratios of below 10\% (Looney 2012). The historical reasons for Pakistan's low tax-to-GDP ratio are long and complicated, but one argument is that it is a consequence of structural inequalities and a large and powerful landowning class that has resulted in significantly constrained income for the government and reduced its ability to finance postdisaster operations (IMF 2017).

The initial emergency response plan sought $\$ 460$ million to enable international partners to support the government of Pakistan in addressing the needs of flood-affected families for the duration of the immediate relief period (United Nations 2010a). As per this Pakistan Initial Floods Emergency Response Plan, further multiagency and government assessments were carried out in the following weeks and an updated plan released in September 2010. This plan updated the total figure requested

7 The Pakistani government, military, and the international humanitarian community were able to keep the death toll relatively low in comparison to the size of the disaster, providing lifesaving assistance to millions of people affected by the floods. Although the area and number of people exceeded the three other disasters mentioned, the 2010 floods killed comparatively few compared to the same disasters: 227,898 dead in the tsunami (Tsunami Evaluation Coalition 2006); 87,350 killed in the 2005 earthquake (Earthquake Engineering Research Institute 2006); and between 160,000 and 220,000 died following the Haitian earthquake (O'Connor 2012). 
for the response phase to $\$ 2.007$ billion. At the time, this was the largest international appeal the UN had ever launched (United Nations 2010b).

Initially, there was some confusion over different assessments and funding requests. The two UN funding plans were compiled in close consultation with the NDMA (set up in 2007 in response to the civilian coordination challenges posed by the 2005 earthquake) (United Nations 2010a, 2010b, Madiwale and Virk 2011). ADB and the World Bank also released a disaster needs assessment (DNA), however, this focused on medium- and longer-term damage and loss estimates and worked closely with the Economic Affairs Division (ADB and World Bank 2010). The initial coordination challenge between the NDMA and the Economic Affairs Division was resolved quickly through a late 2010 law, approved by the federal Parliament, that clarified the roles of the NDMA and other national institutions as well as those at the provincial level (Polastro et al. 2011). Even despite this new law, the NDMA still does not have any legislative authority over any other federal, provincial, or district organization, including the provincial disaster management authorities (NDMA 2011).

The Pakistani military was the first domestic organization to respond at scale and provided lifesaving assistance to hundreds of thousands. Over 60,000 military personnel; 67 helicopters; and all available C-130 planes; 1,238 boats along with various community organizations undertook the task to rescue stranded people (1.4 million); provide them with rations (409,000 tons of food); tents (488,000); tarpaulins (931,000); blankets (1.9 million); and medical care (to 5.9 million people) (Government of Pakistan 2011). The military also set up field hospitals, mobile veterinary teams, and over 100 relief camps (Madiwale and Virk 2011). Pakistan's armed forces spent nearly $25 \%$ of their annual budget on the flood response. Although considered by many communities to have provided much-needed assistance in the response phase that helped avert greater catastrophe, the involvement of the military and its affiliated private companies have caused some consternation in the longer-term recovery from the floods, discussed further below (Madiwale and Virk 2011).

Some of these issues with the postdisaster operations were due to existing structural inequalities, reducing the effectiveness of the response for marginalized communities. A randomized survey of 1,769 households undertaken in collaboration with the World Health Organization found satisfaction with the humanitarian response was low, with $40 \%$ of respondents stating they were "very unsatisfied" with the humanitarian assistance 1 month, 3 months, and 6 months after the floods. Interestingly, $65.3 \%$ of respondents had absolutely no formal education, suggesting that they were among the most vulnerable yet least satisfied with the response (Kirsch et al. 2013).

In addition to low levels of humanitarian assistance to some of the most vulnerable communities, low levels of humanitarian funding went to national NGOs. These local actors considered it difficult to apply for financing as procedures were not known to many or were considered overly cumbersome, exemplifying low levels of familiarity with the disaster management architecture, domestically and internationally (Polastro et al. 2011).

In the aftermath of the 2007 floods, which affected Balochistan and parts of southern Sindh, recommendations focusing on developing national capacities as first responders were not followed through (Polastro et al. 2011). For example, in the 2010 floods, agencies procured relief items from Islamabad, as opposed to provincially or locally, increasing logistical costs and making the unit cost much more expensive, and potentially undermining local economies. This was so, even though many materials were available in local markets in the affected areas (Murtaza et al. 2011). National NGOs were less funded than international NGOs and generally reported a feeling of marginalization from 
international funding. One Department of Social Welfare official complained that international organizations working in Rajanpur district (in Punjab province) should make more effort to work with local NGOs, to build their capacity and knowledge of emergency response, as the national NGOs will remain after the international NGOs have left (Murtaza et al. 2011). ${ }^{8}$

The evident statement that national staff and organizations have a stronger grasp of the context was implicitly recognized by response organizations, despite not working with local organizations nor localizing the response in traditional ways. Agencies emphasized the recruitment and secondment of experienced staff nationally, so that previous lessons learned can be incorporated in programs (Murtaza et al. 2011). Many agencies benefited from the capacity built in previous emergencies in terms of experience in responding to and using organization systems. Interestingly, it seemed agencies broadly relied on individuals' learning by doing rather than any systematic, institutionalized processes of shared learning (Murtaza et al. 2011).

In addition to national staff with extensive experiential knowledge of the Pakistani context, it was primarily organizations with longstanding presence in the country that immediately mobilized staff and contingency stocks (Polastro et al. 2011). In KPK, agencies were able to respond quickly due to their existing presence responding to the crisis of internally displaced people, whereas in provinces with very few existing agencies, such as Punjab and Sindh, there were delays of up to 1 month in responding to the floods (Murtaza et al. 2011). This experiential knowledge was born out of the decision to locate humanitarian coordination bases close to affected areas. For example, in Punjab province, the UN decided to coordinate operations from Multan not Lahore, receiving praise from operational organizations, but perceived as disconnected and a parallel structure by the government (Polastro et al. 2011).

Differences in approach between national and international actors were also evident in the formal institutional processes related to financing the postdisaster operations. Donors opted to contribute to the UN response plan, however, this plan was not officially endorsed by the government due to disagreement on the scope of the plan (i.e., the number of clusters and whether it should include early recovery activities, or if this should be part of a separate appeal). The disagreement nearly compromised the relationship between the government and the UN and represented a serious breakdown in trust (NDMA 2011). The government finally endorsed the UN appeal in November 2010 (as Pakistan Floods Relief and Early Recovery Response Plan).

There were competing funding priorities in Pakistan and globally in 2010. The Pakistan Humanitarian Response Plan, addressing the needs of an estimated 2.6 million internally displaced people, received less attention and funding (50.2\% of the appeal) (UNOCHA 2018b). The Haiti earthquake had demanded both financial and human resources from the humanitarian system as well.

In contrast to the other case studies in this paper, most of the donor funding for the Pakistan 2010 floods focused on emergency relief and early recovery (Polastro et al. 2011, Kirsch et al. 2013). The Strategic Early Recovery Action Plan (prepared in April 2011), received 85\% of the requested

8 Although the international relief efforts could have engaged more with local actors (both local suppliers and local civil society actors), the recovery was sped up thanks to the efforts of the Government of Pakistan. The government exempted relief goods from taxes and granted visas upon arrival to the humanitarian personnel deployed (Polastro et al. 2011). The provisions outlined in the National Disaster Management Act 2010 have been reviewed favorably. However, it has been noted that the strength of International Disaster Response Law components could be further strengthened, such as registering international actors during emergencies (International Federation of the Red Cross 2014). 
$\$ 1.195$ billion (NDMA 2012). Reconstruction funding is much harder to account for, as there is no equivalent to the United Nations Office for the Coordination of Humanitarian Affairs Financial Tracking Service, nor any way of tracking development contributions to projects addressing recovery and reconstruction issues (NDMA 2012, Hallwright and Handmer 2019).

The government acted on some of the recommendations outlined in the DNA, specifically those regarding next steps for rehabilitation and reconstruction. The national oversight disaster management council was established on 16 September 2010 to oversee, facilitate, and coordinate postdisaster operations, monitor funds, ensure effective targeting, and report progress. The government established the National Flood Reconstruction Plan, launched in February 2011 (Government of Pakistan 2011), and the flood reconstruction unit in the planning commission was established to operationalize the plan. ${ }^{9}$ The reconstruction plan adopts the first option presented in the DNA due to resource constraints. This is still a significant cost to bear-PKR613 billion ( $\$ 7.17$ billion) and the government has been trying to raise funds to finance this, the cheapest of the three options. ${ }^{10}$ Key to its success is the involvement of the private sector, through public-private partnerships, amounting to PKR113 billion (\$1.33 billion) (NDMA 2012).

Importantly, close coordination with the military was critical in both the response and reconstruction phases. This is markedly different than most countries (Indonesia perhaps being another regional example) in which domestic military actors play an important role in the response but are not involved in the recovery efforts." The National Highways Authority received many grants and loans following the 2010 floods due to its mandated responsibilities, for example, the Flood Emergency Reconstruction Project (ADB 2016).

The Benazir Income Support Programme was used to rapidly support the affected population with small cash grants of PKR4,000 only weeks after the floods. Approximately 1.48 million Watan cards were distributed, with funds disbursed at PKR27.7 billion (Government of Pakistan 2011). Unfortunately, many lacked the basic infrastructure needed to access this assistance (i.e., lack of automated teller machines and knowledge of their usage). Furthermore, the international community did not work with the government to complement this assistance, either through in-kind material goods or through using this existing welfare system to distribute international cash transfers (Polastro et al. 2011).

In summary, the early recovery activities under the Early Recovery Plan delivered strong support through a coordinated mechanism. That said, further early recovery and longer-term reconstruction efforts have been hampered by both a lack of funding and complications arising from further disasters, such as the 2011 floods. Pakistani communities continue to be at significant risk of repeated catastrophes, further highlighting the need to understand and enact both explicit and tacit enablers of disaster management, including disaster risk financing.

9 The National Flood Reconstruction Plan outlines the governance of the government's recovery efforts. The Council of Common Interest is to be the overarching policy-making body that provides policy guidance to all Pakistani governments. It will ensure the rationale allocation of reconstruction resources and resolve interprovincial issues on reconstruction policy and implementation.

$10 \quad \$ 1=$ PKR141.69 as of 14 May 2019.

1 Experienced, well organized, and well resourced, the Pakistan military is more than an armed force-it has extensive economic interests (Madiwale and Virk 2011). This is best exemplified by the ongoing recovery projects, many of whose contracts have been won by military companies. The National Highways Authority is a military-controlled private company who is responsible for developing and maintaining Pakistan's national highways. 


\section{DISCUSSION AND CONCLUSIONS}

The three cases reviewed in this article highlight common as well as context-specific challenges associated with the financing and implementation of postdisaster operations. In all three cases, there were explicit efforts to set up disaster risk management institutions (through, for example, the drafting of national response frameworks, setting up national disaster response funds, and numerous standard operating procedures), which helped facilitate postdisaster operations. However, operations stalled for many reasons, as might be expected in extraordinary events, such as the ones reviewed in this paper. In all three cases, access to postdisaster finance constituted only a small part of what enables postdisaster operations. Tacit factors such as the weakening of mutual trust between external and internal actors, lack of experiential knowledge as opposed to propositional knowledge and formal procedures, lack of last-mile delivery infrastructure, and limited capacities all hampered postdisaster financing and operations. These tacit factors are likely to be overlooked when setting up formal disaster response and financing policies, yet are crucial enabling factors for postdisaster operations. Below, we outline five major lessons learned through these case studies regarding the enabling environment for postdisaster operations.

1. The disaster risk finance system should be as inclusive as possible to build system and community resilience and strengthen mutual accountability. Responding to disasters effectively requires a broad engagement of stakeholders across humanitarian and development sectors at the international, national, and local levels along with the support of others, including domestic and foreign militaries. The experiences of the three case studies show that internationally led and topheavy governance systems are prone to implementation failures and poor local relevance; so are separate efforts to engage stakeholders by humanitarian and development communities. ${ }^{12}$ The formal national and international disaster management systems should actively engage with local NGOs and private sector partners, including working toward operational cohesion. The system should actively build community resilience as the three cases illustrated that communities themselves are the first to respond (almost always with no injection of external finance) to disasters and are key to ensuring sustained recovery and reconstruction. The efforts of a number of donors including Australia, Denmark, France, and Switzerland to put in place measurable targets (such as percentage of funding allocated for local capacity building) to require or incentivize local partnerships should be scaled up in nondisaster times. As these cases amply illustrate, a risk of corruption hinders trusting working relationships, adding a further layer of complication in times of disasters. Widening access to improved financial tracking systems, assessing corruption risks throughout postdisaster operations (e.g., building on corruption risk mapping conducted for the humanitarian sector by Ewins et al. [2006]), and broadly sharing anticorruption awareness and capacity building activities (e.g., building on those developed for the humanitarian sector by the International Federation of the Red Cross and Transparency International Norway (Warner et al. 2014) will increase the mutual accountability of the disaster risk finance system.

2. Financial delivery mechanisms should be strengthened-including via the use of cash transfer preparedness programming - and should stress test a country's absorptive capacity. In all three cases, delivery assistance faced significant challenges due to underdeveloped financial infrastructure and other contextual barriers. The approach to cash delivery needs a profound shift from a mere tweaking of traditional bank accounts. Technologies such as mobile transfers and

12 These lessons are in part reflected in the Grand Bargain commitment, with which major donors and aid agencies globally are currently pledging to channel $25 \%$ of international humanitarian funding to local and national actors by 2020 (UNOCHA 2018c). Localization markers to track humanitarian financing are now being developed. 
electronic vouchers offer new avenues for the swift delivery of resources (CSR-Asia 2014); while many governments are now setting up adaptive social protection schemes that scale up during emergencies (ADB 2018a, O'Brien et al. 2018). National and subnational governments working together with partners should invest in cash transfer preparedness programs, including the establishment of a public registry and the predisaster identification of potential beneficiaries for public assistance, and the setting of rules and operational procedures for distributing resources to households and communities, as in Pakistan when the 2010 floods occurred. The governance complexity of these cases show that having readily available finance per se was only part of the solution, and that society's absorption capacity became important in a highly stressful environment. Any evaluation and simulation exercises for disaster risk financing and contingency plans should therefore include testing the absorptive capacity of governments and partners, including their ability to handle a dramatic increase in highly fragmented, multiple currency grants and loans, and their expertise to implement complex reconstruction projects. Stress testing should aim at identifying the limit of existing national disaster risk management system to cope with risk, and at clarifying expectation as to when external assistance will be needed, and how the national system can be built to make the best use of such external assistance.

3. Establish and maintain programs to build trust and partnerships between internal and external actors in nondisaster times. Trusting working relationships, as well as operational and cultural awareness, were important tacit enabling factors for postdisaster operation in all three cases. To facilitate these enabling environments, one could set up, for example, a peer-to-peer mentoring program of national and subnational government officials and partners to strengthen understanding of the international disaster risk financing system and associated processes (e.g., the Climate Action Peer Exchange program initiated by the World Bank (World Bank 2017b); or communities of practice among development practitioners, the international humanitarian sector, and the national disaster management system, to reduce the risk of operational difficulties born from a lack of familiarity across the three sectors (e.g., the transforming surge capacity project piloted in the Philippines and Pakistan [Start Network n.d.]). Such groups can also review the disaster risk financing system, its effectiveness and its efficiency, such as is currently being facilitated by ADB in Pakistan (ADB 2018b).

4. Roles and responsibilities of actors should be clear in all phases of postdisaster operations; actors' experiential knowledge should be developed through training that simulates stressful situations. An emphasis should be placed on setting clear departmental mandates within national governments regarding the coordination of financing, operations, and monitoring of disaster response, recovery, as well as reconstruction activities. Predisaster efforts should clarify roles and responsibilities across government departments and their relationships to international and domestic partners from private and civil society sectors. Often missing in the contingency planning are plans for a smooth transition from the emergency response to medium- to long-term recovery and reconstruction. The cases above also showed that setting up of explicit rules and systems is only part of the solution. Local staff and partners should have sufficient training and experiential knowledge prior to disasters so that they may effectively follow plans and procedures under the time-pressed postdisaster environments. Capacity building programs should therefore be targeted at both national and local actors (including government, private sectors, and NGO entities) and elaborate on aspects such as operational processes and requirements related to external disaster risk financing and ways of making the domestic financial system ready to scale up operations, in case of disaster events. Training should include simulating highly stressful and chaotic environments for participants. 
5. Donors can develop detailed guidance on disaster risk financing outlining the common challenges and ways to overcome these, and also facilitate and harmonize their financing requirements, including the use of languages other than English. In all three cases, government officials and partners struggled to navigate the byzantine disaster finance landscape. One effective solution to this issue would be to provide guidance notes targeted at both national and subnational governments and partners. Such guidance should detail the processes for ex ante and ex post financing options as well as providing mitigation measures for some of the common operational pitfalls, such as ways to align postdisaster spending with overall development and resilience building objectives. To facilitate shared understanding, such guidance should be prepared in English as well as in local languages. In addition to raising awareness and operational capacity of recipient countries, donor communities, governments, and aid agencies working together should advocate for reduced complexity in bilateral and multilateral requirements and processes to access disaster risk financing. For example, a simple measure would be to publish and accept financing proposals in languages other than English and to harmonize operational procedures and documentations required for handling disaster risk financing. At the same time, donors should also support the national adoption of legal instruments to expedite large increases in importing goods following a disaster, through the adoption of the International Disaster Response Law (International Federation of the Red Cross 2013), outlining the common legal conditions under which visas and permits and any taxes or fees from remittances may be waived. 


\section{REFERENCES}

Asia Foundation. 2017. "Aid and Recovery in Post-Earthquake Nepal: Synthesis Report (Phase 4)." The Asia Foundation: San Francisco. https://asiafoundation.org/wp-content/uploads/2017/10/Aidand-Recovery-in-Post-Earthquake-Nepal-Synthesis-Report-Phase-4-1.pdf.

Asian Development Bank (ADB). 2016. "Pakistan: Flood Emergency Reconstruction Project Completion Report (No. Project Number: 44372-013)." Manila. https://www.adb.org/sites/ default/files/project-document/197196/44372-013-pcr.pdf.

_ 2017. "Vanuatu: Cyclone Pam Road Reconstruction Project - Additional Financing." Manila.

. 2018a. "Strengthening Resilience Through Social Protection Guidance Note." Manila. https://www.adb.org/sites/default/files/institutional-document/412011/resilience-socialprotection-guidance-note.pdf.

2018b. “ADB, Partners Review Financial Preparedness for Disaster Response in Pakistan.” 25 April. Manila. https://www.adb.org/news/adb-partners-review-financial-preparednessdisaster-response-pakistan.

Asian Development Bank (ADB) and World Bank. 2010. "Pakistan Floods 2010: Preliminary Damage and Needs Assessment." Islamabad. https://siteresources.worldbank.org/PAKISTANEXTN/ Resources/293051-1264873659180/6750579-1291656195263/PakistanFloodsDNA _December2010.pdf.

AsiaNews. 2015. "Eight Months after the Earthquake, Kathmandu Starts Reconstruction." 17 December. $\quad$ http://www.asianews.it/news-en/Eight-months-after-the-earthquake,Kathmandu-starts-reconstruction-36182.html.

Auerbach, Paul S. 2015. "Preparedness Explains Some Differences between Haiti and Nepal's Response to Earthquake.” 5 June. BMJ: British Medical Journal. https://doi.org/10.1136/ bmj.h3059.

Barber, Rebecca. 2015. “One Size Doesn't Fit All Tailoring the International Response to the National Need Following Vanuatu's Cyclone Pam. A Contribution to the Pacific Regional Consultation for the World Humanitarian Summit." 29 June. Melbourne: Save the Children Australia, CARE Australia, Oxfam Australia, and World Vision Australia. https://reliefweb.int/report/ vanuatu/one-size-doesn-t-fit-all-tailoring-international-response-national-need-following.

Becerra, Oscar, Eduardo Cavallo, and Ilan Noy. 2014. "Foreign Aid in the Aftermath of Large Natural Disasters." Review of Development Economics 18 (3): 445-60.

Bisri, Mizan Bustanul Fuady, and Shohei Beniya. 2016. "Analyzing the National Disaster Response Framework and Inter-Organizational Network of the 2015 Nepal/Gorkha Earthquake." Procedia Engineering 159: 19-26.

Clarke, Daniel Jonathan, and Stefan Dercon. 2016. Dull Disasters? How Planning Ahead Will Make a Difference. Oxford: Oxford University Press. 
Cook, Alistair, Maxim Shrestha, and Zin Bo. 2016. "International Response to 2015 Nepal Earthquake Lessons and Observations.” NTS Report No. 4. Singapore: Centre for Non Traditional Security Studies.

CSR-Asia. 2014. "Business Briefing: Electronic Cash Transfers in Disaster Response - Opportunities for Business Engagement." Hong Kong, China: CSR-Asia.

Dahal, Ramesh Kumar. 2016. "Earthquake Recovery Process in Nepal (A Comparative Analysis with Haiti).” Clark University Master's Research Paper. International Development, Community, and Environment 40. https://commons.clarku.edu/idce_masters_papers/40/.

Development Initiatives. 2018. "Global Humanitarian Assistance Report 2018." Development Initiatives: Bristol, United Kingdom. http://devinit.org/wp-content/uploads/2018/06/GHAReport-2018.pdf.

Earthquake Engineering Research Institute. 2006. "The Kashmir Earthquake of October 8, 2005 : Impacts in Pakistan." 28 February. Oakland: Earthquake Engineering Research Institute. https://reliefweb.int/report/pakistan/kashmir-earthquake-october-8-2005-impacts-pakistan.

Ewins, Pete, Paul Harvey, Kevin Savage, and Alex Jacobs. 2006. "Mapping the Risks of Corruption in Humanitarian Action." Berlin: Transparency International. https://interagencystanding committee.org/content/mapping-risk-corruption-humanitarian-assistance-july-2006.

Fink, Guenther, and Silvia Redaelli. 2009. "Determinants of International Emergency AidHumanitarian Need Only?" Policy Research Working Paper No. 4839. Washington, DC: World Bank. http://documents.worldbank.org/curated/en/949201468163753597/pdf/WPS4839.pdf.

Garschagen, Matthias, Michael Hagenlocher, Martina Comes, Mirjam Dubbert, Robert Sabelfeld, Yew Jin Lee, Ludwig Grunewald, Matthias Lanzendörfer, Peter Mucke, Oliver Neuschäfer, Simone Pott, Joachim Post, Stephanie Schramm, Dorit Schumann-Bölsche, Bruno Vandemeulebroecke, Torsten Welle, Joern Birkmann. 2016. World Risk Report 2016. Bündnis Entwicklung Hilft and UNU-EHS. http://collections.unu.edu/view/UNU:5763\#viewAttachments.

Ghesquiere, Francis, and Olivier Mahul. 2010. "Financial Protection of the State against Natural Disasters: A Primer.” Policy Research Working Paper No. 5429. Washington, DC: World Bank.

Giri, Sanjeev, and Chandan Kumar Mandal. 2018. "Three Years On, Cash Crunch Hinders Post-Quake Reconstruction.” Kathmandu Post. 1 April. http://kathmandupost.ekantipur.com/news/201804-01/three-years-on-cash-crunch-hinders-post-quake-reconstruction.html.

Goda, Katsuichiro, Takashi Kiyota, Rama Mohan Pokhrel, Gabriele Chiaro, Toshihiko Katagiri, Keshab Sharma, and Sean Wilkinson. 2015. "The 2015 Gorkha Nepal Earthquake: Insights from Earthquake Damage Survey.” Frontiers in Built Environment. doi: 10.3389/fbuil.2015.00008.

Government of Australia. 2017. Humanitarian Assistance in the Pacific: An Evaluation of the Effectiveness of Australia's Response to Cyclone Pam (Evaluation). Canberra: Department of Foreign Affairs and Trade. Office of Development Effectiveness. 
Government of Germany. 2016. "Post-Pam: Lessons Learned for [German] Development Cooperation in Vanuatu and the Pacific." Bonn: Deutsche Gesellschaft für Internationale Zusammenarbeit $\mathrm{GmbH}$.

Government of Nepal. 2013. "National Disaster Response Framework (NDRF).” Kathmandu: Ministry of Home Affairs. http://un.org.np/sites/default/files/NDRF_English\%20version_July-2013.pdf.

_ 2015. "Post Disaster Needs Assessment Vol. B: Sector Reports.” Kathmandu: National Planning Commission. https://www.npc.gov.np/images/category/PDNA_volume_BFinalVersion.pdf.

- 2017. Nepal Disaster Report 2017: The Road to Sendai. http://drrportal.gov.np/uploads/ document/1321.pdf.

Government of New Zealand. 2017. "Independent Evaluation of the Vanuatu Country Programme: Aid Proliferation in Vanuatu.” Wellington: Ministry of Foreign Affairs and Trade.

Government of Pakistan. 2010. "Pakistan 2010: Preliminary Damage and Needs Assessment." Islamabad. https://www.adb.org/sites/default/files/linked-documents/44372-01-pak-oth-02.pdf.

_-_- 2011. "National Flood Reconstruction Plan 2010.” Islamabad: Flood Reconstruction Unit, Planning Commission.

Government of Vanuatu. 2014. "Budget 2014, Volume 1 \& 2.” Port Vila. https://doft.gov.vu/ images/volume_1_2014.pdf.

2015a. "Tropical Cyclone Pam: Humanitarian Action Plan." Port Vila.

2015b. "National Recovery and Economic Strengthening Program Plan (Draft for Council of Ministers).” Port Vila.

Grünewald, François, and Anne Burlat. 2016. "Nepal Earthquake: A Rapid Review of the Response and a Few Lessons Learns." Plaisance, France: Urgence, Rehabilitation, Developpement. https://www.urd.org/IMG/pdf/Lessons_learnt_and_areas_to_be_improved_in_Nepal_response.pdf.

Hall, Mary, Andrew C.K. Lee, Chris Cartwright, Sujan Marahatta, Jiban Karki, and Padam Simkhada. 2017. "The 2015 Nepal earthquake disaster: lessons learned one year on." Public Health 145: $39-44$

Hallegatte, Stephane, Maruyama Rentschler, and Jun Erik. 2018. "The Last Mile: Delivery Mechanisms for Post-Disaster Finance.” Washington, DC: World Bank. http://documents.worldbank.org/ curated/en/813701537285938605/The-Last-Mile-Delivery-Mechanisms-for-Post-DisasterFinance.

Hallwright, Joshua, and John Handmer. 2019. "Accountability and Transparency in Disaster Aid: Cyclone Pam in Vanuatu." International Journal of Disaster Risk Reduction. 101104. 10.1016/j.ijdrr.2019.101104.

Handmer, John, and Hannah Iveson. 2017. "Cyclone Pam in Vanuatu: Learning from the Low Death Toll." Australian Journal of Emergency Management 32 (2): 60-65. 
Hashmi, Hashim Nisar, Qazi Tallat Mahmood Siddiqui, Abdul Razzaq Ghumman, Mumtaz Ahmed Kamal, and Habib ur Rehman Mughal. 2012. "A Critical Analysis of 2010 Floods in Pakistan." African Journal of Agricultural Research 7 (7): 1054-67. https://academicjournals.org/ journal/AJAR/article-abstract/ED4193144814.

Hobbs, Christina, and Rosie Jackson. 2016. "Cash Transfer Programming in the Pacific: A Feasibility Scoping Study." Canberra: Government of Australia Department of Foreign Affairs and Trade, Cash Learning Partnership.

Hochrainer-Stigler, Stefan. 2006. Macroeconomic Risk Management Against Natural Disasters: Analysis Focused on Governments in Developing Countries. Wiesbaden: Deutscher Universitaetsverlag.

Insurance Asia News. 2018. "Only 8\% of Asia-Pacific Disaster Losses Covered, Says UN." 2 July. https://insuranceasianews.com/only-8-of-asia-pacific-disaster-losses-are-covered-un/.

Inter-Agency Standing Committee. 2016. "Preparedness: What Can We Learn from the Nepal Response?" New York: United Nations Office for the Coordination of Humanitarian Affairs. http://www.deliveraidbetter.org/webinars/preparedness/.

International Bank for Reconstruction and Development (IBRD)/World Bank and ADB. 2017. Assessing Financial Protection against Disasters: A Guidance Note on Conducting a Disaster Risk Finance Diagnostic. https://www.adb.org/sites/default/files/publication/330846/assessingfinancial-protection-against-disasters.pdf.

International Centre for Integrated Mountain Development. 2015. “Nepal Earthquake 2015." http://www.icimod.org/nepalearthquake2015.

International Federation of the Red Cross. 2013. Model Act for the Facilitation and Regulation of International Disaster Relief and Initial Recovery Assistance (with commentary). http://www.ifrc.org/PageFiles/125656/MODEL\%20ACT\%20INGLES.pdf.

2014. International Disaster Response Law (IDRL) in Pakistan. IFRC. http://adore.ifrc.org/Download.aspx?Fileld=62003\&.pdf.

International Monetary Fund (IMF). 2015. "Nepal: Request for Disbursement Under the Rapid Credit Facility." Washington, DC. https://www.imf.org/en/Publications/CR/Issues/2016/12/31/NepalRequest-for-Disbursement-Under-the-Rapid-Credit-Facility-43173.

_ 2016. "Vanuatu: 2016 Article IV Consultation-Press Release; Staff Report; and Statement by the Executive Director for Vanuatu." Washington, DC. https://www.imf.org/en/ Publications/CR/Issues/2016/12/31/Vanuatu-2016-Article-IV-Consultation-Press-ReleaseStaff-Report-and-Statement-by-the-44361.

2017. "Pakistan: 2017 Article IV Consultation-Press Release; Staff Report; Informational Annex; and Statement by the Executive Director for Pakistan." Washington, DC. https://www.imf.org/en/Publications/CR/Issues/2017/07/13/Pakistan-2017-Article-IVConsultation-Press-Release-Staff-Report-Informational-Annex-and-45078. 
- 2018. "IMF Rapid Credit Facility (RCF)." Washington, DC. https://www.imf.org/en/ About/Factsheets/Sheets/2016/08/02/21/08/Rapid-Credit-Facility.

Kirsch, Thomas, Muhammad Ahmed Siddiqui, Paul Clayton Perrin, W. Courtland Robinson, Lauren M. Sauer, and Shannon Doocy. 2013. "Satisfaction with the Humanitarian Response to the 2010 Pakistan Floods: A Call for Increased Accountability to Beneficiaries.” Emergency Medicine Journal 30 (7): 565-71. https://doi.org/10.1136/emermed-2012-201226.

Lloyd-Jones, Tony. 2006. "Mind the Gap! Post-Disaster Reconstruction and the Transition from Humanitarian Relief." A report produced for the Royal Institute of Chartered Surveyors by the Max Lock Centre at the University of Westminster. https://www.preventionweb.net/ publications/view/9080.

Logistics Cluster. 2015. "Nepal Lessons Learned Report.” Rome: Logistics Cluster (designated by the United Nations Inter-Agency Standing Committee; led by The World Food Programme). https://logcluster.org/global-meeting-document/nepal-lessons-learned-report.

Looney, Robert. 2012. "Economic Impacts of the Floods in Pakistan." Contemporary South Asia 20 (2): 225-41. https://doi.org/10.1080/09584935.2012.670203.

Madiwale, Ajay, and Kudrat Virk. 2011. "Civil-Military Relations in Natural Disasters: A Case Study of the 2010 Pakistan Floods." International Review of the Red Cross 93 (884): 1085-105. https://doi.org/10.1017/S181638311200032X.

Mechler, Reinhard. 2004. "Natural Disaster Risk Management and Financing Disaster Losses in Developing Countries.” 18 July. Karlsruhe: Verlag fuer Versicherungswissenschaft.

Murtaza, Niaz, Sajjad Akhtar, Noor Mohammed, Sarah Harrison, Sahar Bhatti, and Silva Ferretti. 2011. The DEC Real-Time Evaluation Report, 36.

National Disaster Management Authority (NDMA). 2011. "Pakistan Floods 2010: Learning from Experience." Islamabad: Prime Minister's Secretariat. http://www.ndma.gov.pk/publications/ SPakistanFloods-\%20Flood\%202010.pdf.

2012. "Early Recovery Floods 2010 Final Report - Relief Saves Lives Early Recovery Builds Futures." Islamabad: Prime Minister's Secretariat.

National Reconstruction Agency. 2016. "Nepal Earthquake 2015 Post Disaster Recovery Framework 2016-2020.” https://reliefweb.int/report/nepal/nepal-earthquake-2015-post-disasterrecovery-framework-2016-2020.

2018. "Reconstruction Progress in Numbers." 2 May. http://www.nra.gov.np/en/mapinfograhics/All Infographics/0.

O'Brien, Clare, Rebecca Holmes, Zoë Scott, and Valentina Barca. 2018. "Shock-Responsive Social Protection Systems Toolkit: Appraising the Use of Social Protection in Addressing Large-Scale Shocks." https://www.opml.co.uk/files/Publications/a0408-shock-responsive-socialprotection-systems/srsp-toolkit.pdf?noredirect=1. 
O’Connor, Maura. 2012. "Two Years Later, Haitian Earthquake Death Toll in Dispute." Columbia Journalism Review. 12 January. https://www.cjr.org/behind_the_news/one_year_later_haitian _earthqu.php.

Olsen, Gorm Rye, Nils Carstensen, and Kristian Høyen. 2003. "Humanitarian Crises: What Determines the Level of Emergency Assistance? Media Coverage, Donor Interests and the Aid Business." Disasters 27 (2): 109-26.

Olshansky, Robert B., Lewis Hopkins, and Laurie Johnson. 2012. “Disaster and Recovery: Processes Compressed in Time." Natural Hazards Review 13 (3): 173-78.

Onlinekhabar. 2018. "Nepal Govt to Dissolve Non-Functional Post-Quake Reconstruction Fund." http://english.onlinekhabar.com/nepal-govt-to-dissolve-non-functional-reconstruction-fund.html.

Organisation for Economic Co-Operation and Development (OECD). 2015. "Disaster Risk Financing A Global Survey of Practices and Challenges.” Paris. http://www.oecd.org/daf/fin/insurance/ OECD-Disaster-Risk-Financing-a-global-survey-of-practices-and-challenges.pdf.

Oxfam. 2019. "Vanuatu Cash Transfer Feasibility Assessment." https://www.preventionweb.net/ files/globalplatform/5cda5138a0a2aOxfam_Vanuatu_CTP_Report_FINAL.pdf.

Pacific Catastrophe Risk Assessment and Financing Initiative (PCRAFI). "Pacific Risk Information System: Open DRI Repository for the Pacific Region Providing Premiere Risk-Related Geospatial Datasets." http://pcrafi.spc.int/ (accessed 17 May 2019).

Polastro, Ricardo, Aatika Nagrah, Nicolai Steen, and Farwa Zafar. 2011. Inter-Agency Real Time Evaluation of the Humanitarian Response to Pakistan's 2010 Flood Crisis. Geneva: Inter-Agency Standing Committee.

Practical Action. 2016. "Supply Chain of Construction Materials in Earthquake Affected Districts. An assessment in Nuwakot and Rasuwa." https://practicalaction.org/knowledge-centre/ resources/supply-chain-assessment-report-nuwakot-and-rasuwa/.

Rahman, Aminur, and Yasuyuki Sawada. 2012. "Can Donor Coordination Solve the Aid Proliferation Problem?” Economics Letters 116 (3): 609-12.

Raschky, Paul Anton, and Manijeh Schwindt. 2012. "On the Channel and Type of Aid: The Case of International Disaster Assistance." European Journal of Political Economy 28 (1): 119-31.

Scott, Michon. 2011. "Heavy Rains and Dry Lands Don't Mix: Reflections on the 2010 Pakistan Flood." https://earthobservatory.nasa.gov/Features/PakistanFloods.

Sharma, Keshab, Apil K.C., Mandip Subedi, and Bigul Pokharel. 2018. "Challenges for Reconstruction after Mw 7.8 Gorkha Earthquake: A Study on a Devastated Area of Nepal.” Geomatics Natural Hazards and Risk 9 (1): 760-90.

South Asian Watch on Trade, Economics, and Environment (SAWTEE). 2018a. "Economic Implications of Post-Disaster Reconstruction." Policy Brief 39. http://www.sawtee.org/ publications/Policy_Brief_39.pdf. 
_ 2018b. "Nepal's Post-Disaster Reconstruction Current Status and Lessons Learnt." Policy Brief 36. http://www.sawtee.org/publications/Policy-Brief-36.pdf.

Southeast Asia Disaster Risk Insurance Facility (SEADRIF). https://www.seadrif.org/ (accessed 28 August 2019).

Start Network. n.d. "The Transforming Surge Capacity Project." https://startnetwork.org/startengage/transforming-surge-capacity.

Tsunami Evaluation Coalition. 2006. Synthesis Report and Thematic Evaluation Set. London: Tsunami Evaluation Coalition.

United Nations. 2010a. "Pakistan Initial Floods Emergency Response Plan.” Rome: United Nations Food and Agriculture Organization. http://www.fao.org/3/a-bl123e.pdf.

- 2010b. "Pakistan Floods Emergency Response Plan: Revision.” New York: United Nations Children's Fund [UNICEF]. https://reliefweb.int/sites/reliefweb.int/files/resources/ F7DF1753A774D98F852577A10077BCAA-Full_Report.pdf.

United Nations Economic and Social Commission for Asia and the Pacific (UNESCAP). 2017. "DISASTERS WITHOUT BORDERS Regional Resilience for Sustainable Development." New York. https://www.unescap.org/sites/default/files/Full\%20Report\%20\%20\%5BLow-Res\%5D.pdf.

United Nations Office for the Coordination of Humanitarian Affairs [UNOCHA]. 2015a. "Nepal Earthquake Humanitarian Response: April to September 2015." New York. https://reliefweb.int/sites/reliefweb.int/files/resources/nepal_earthquake_humanitarian_resp onse_report_lr.pdf.

_. 2015b. "Note on Migration and Remittances." New York. https://reliefweb.int/report/ nepal/note-migration-and-remittances-24072015.

_ 2015c. "Flash Appeal: Emergency Response Plan for Vanuatu Tropical Cyclone Pam MarchJune 2015." New York.

- 2018a. "Disaster Response in Asia and the Pacific: A Guide to International Tools and Services, 2nd Edition.” New York. https://reliefweb.int/sites/reliefweb.int/files/resources/ ROAP_DisasterGuide.pdf.

_ 2018b. “Financial Tracking Service: Pakistan.” New York. https://fts.unocha.org/appeals/330/ summary.

_. 2018c. "2018 Grand Bargain (Hosted by the Inter-Agency Standing Committee)." New York. https://interagencystandingcommittee.org/grand-bargain-hosted-iasc.

Vachette, Astrid, David King, and Alison Cottrell. 2017. "Bonding, bridging and linking social networks: A qualitative study of the emergency management of Cyclone Pam, Vanuatu: Cyclone Pam in Vanuatu." Asia Pacific Viewpoint 58(3), 315-330. https://doi.org/10.1111/apv.12150. 
Warner, Amanda, Gro Skaaren-Fystro, Anne Signe Hørstad, Julie Bastarache, and Nancy Claxton. 2014. "Preventing Corruption in Humanitarian Aid - Basic Training. Design Document." Geneva: International Federation of the Red Cross. http://www.ifrc.org/PageFiles/99169/ Annex\%20VI\%20-Preventing_Corruption_Basic_Training_Design_Document_v2_final.pdf.

World Bank. 2015. "Fiscal Disaster Risk Assessment: Options for Consideration, Pakistan (No. 94474PK).” Washington, DC. http://documents.worldbank.org/curated/en/829791468070733917/ pdf/944740WPOP13260terORisk0Assessment.pdf.

_. 2017a. "Sovereign Catastrophe Risk Pools: World Bank Technical Contribution to the G20." https://openknowledge.worldbank.org/handle/10986/28311.

- 2017b. "CAPE: A Peer-to-Peer Knowledge Exchange for Finance Ministers to Combat Climate Change." Washington, DC. http://www.worldbank.org/en/news/feature/2017/05/10/cape-apeer-to-peer-knowledge-exchange-for-finance-ministers-to-combat-climate-change.

World Bank/Global Facility for Disaster Risk Reduction. 2012. "ASEAN Advancing Disaster Risk Financing and Insurance in ASEAN Member States: Framework and Options for Implementation." Washington, DC. https://www.gfdrr.org/sites/gfdrr/files/publication/ DRFI_ASEAN_REPORT_June12.pdf.

World Food Programme. 2015a. "Vanuatu Tropical Cyclone Pam Version 1." Rome. https://reliefweb.int/sites/reliefweb.int/files/resources/Vanuatu_emergency72hrs_Version\%201.pdf.

_. 2015b. "Nepal Opens First Humanitarian Staging Area, Built with Government \& UK Aid Support.” Rome. https://www.wfp.org/news/news-release/nepal-opens-first-humanitarianstaging-area-built-government-uk-aid-support.

World Health Organization. 2015. "Tropical Cyclone Pam - Vanuatu." 25 March. Geneva. http://www.who.int/hac/crises/vut/vanuatu_donor_alert_25march2015.pdf. 


\section{Enabling Factors for Financing and Implementing Postdisaster Operations}

This paper highlights how governments and other actors can prepare for the governance challenges of disaster response, recovery, and reconstruction. Two sets of enabling factors need to be in place before disaster events occur to help avoid operational pitfalls: 1) explicit enablers - structures and plans, including financing mechanisms and clear roles and procedures; and 2) implicit enablers - trust, knowledge, partnership, and mutual accountability among domestic and external actors. Joint simulation exercises, for example, can help build working relationships and experiential knowledge. The paper's recommendations draw on case studies of the 2015 earthquake in Nepal, Cyclone Pam in Vanuatu (2015), and the 2010 flood in Pakistan.

\section{About the Asian Development Bank}

ADB is committed to achieving a prosperous, inclusive, resilient, and sustainable Asia and the Pacific, while sustaining its efforts to eradicate extreme poverty. Established in 1966, it is owned by 68 members -49 from the region. Its main instruments for helping its developing member countries are policy dialogue, loans, equity investments, guarantees, grants, and technical assistance. 